GH98 - PO - 014

INDONESIAN PETROLEUM ASSOCIATION

Proceedings of the Gas Habitats of SE Asia and Australasia Conference

\title{
SOURCE ROCK IDENTIFICATION IN THE NAM CON SON BASIN OF VIETNAM USING WIRELINE LOGS
}

\author{
Nguyen Quoc Thap*
}

\begin{abstract}
Source rocks in the Nam Con Son Basin are very complex in both distribution and properties. Principal hydrocarbon sources are considered to be Early Miocene and Oligocene paralic sediments, which are regarded as more gas prone. The paralic source rocks consist predominantly of input from higher land plant
\end{abstract}

and bacterial organisms, including both coaly mudrocks and coals. These types of lithologies can be identified with certain confidence by using wireline log data. Wireline logs were utilized for identifying source rock intervals encountered in the wells. An approach to identify source rock was developed and several traditional cross-plots (neutron-density, density-gamma ray, density-sonic and neutron-sonic) were broadened to define source rock intervals as well as hydrocarbon bearing zones. 